\title{
Predoctoral Fellowship-Students with Disabilities
}

National Cancer Institute

\section{Source}

National Cancer Institute. Predoctoral Fellowship-Students with Disabilities. NCI

Thesaurus. Code C18956.

The intent of this Predoctoral Fellowship Program is to encourage students with disabilities to seek graduate degrees and thus further the goal of increasing the number of scientists with disabilities who are prepared to pursue careers in biomedical and behavioral research. These fellowships will provide up to five years of support for research training leading to the Ph.D. or equivalent research degree; the combined M.D./Ph.D. degree; or other combined professional doctorate/research Ph.D. degrees in the biomedical or behavioral sciences. (Predoctoral Fellowship Awards For Students With Disabilities, NIH Guide, Volume 24, Number 5, February 10, 1995) 